\title{
Molecular Detection and Sensitivity to Antibiotics and Bacteriocins of Pathogens Isolated from Bovine Mastitis in Family Dairy Herds of Central Mexico
}

\author{
Ma. Fabiola León-Galván, ${ }^{1,2}$ José E. Barboza-Corona, ${ }^{1,2}$ A. Arianna Lechuga-Arana, ${ }^{3}$ \\ Mauricio Valencia-Posadas, ${ }^{2,3}$ Daniel D. Aguayo, ${ }^{4}$ Carlos Cedillo-Pelaez, ${ }^{5}$ \\ Erika A. Martínez-Ortega, ${ }^{3}$ and Abner J. Gutierrez-Chavez ${ }^{2,3}$ \\ ${ }^{1}$ Food Department, Life Sciences Division, University of Guanajuato, Campus Irapuato-Salamanca, 36500 Irapuato, GTO, Mexico \\ ${ }^{2}$ Graduate Program in Biosciences, Life Sciences Division, University of Guanajuato, Campus Irapuato-Salamanca, \\ 36500 Irapuato, GTO, Mexico \\ ${ }^{3}$ Agronomy Department, Life Sciences Division, University of Guanajuato, Campus Irapuato-Salamanca, \\ 36500 Irapuato, GTO, Mexico \\ ${ }^{4}$ Department of Physics, University of Antwerp, Campus Groenenborger, Groenenborgerlaan 171, 2020 Antwerp, Belgium \\ ${ }^{5}$ Experimental Immunology Laboratory, National Institute of Pediatrics, Ministry of Health, 04530 México, DF, Mexico
}

Correspondence should be addressed to Abner J. Gutierrez-Chavez; ajgutierrez@ugto.mx

Received 6 August 2014; Revised 11 November 2014; Accepted 9 December 2014

Academic Editor: Joel E. López-Meza

Copyright (C) 2015 Ma. Fabiola León-Galván et al. This is an open access article distributed under the Creative Commons Attribution License, which permits unrestricted use, distribution, and reproduction in any medium, provided the original work is properly cited.

\begin{abstract}
Thirty-two farms ( $n=535$ cows) located in the state of Guanajuato, Mexico, were sampled. Pathogens from bovine subclinical mastitis (SCM) and clinical mastitis (CLM) were identified by $16 \mathrm{~S}$ rDNA and the sensitivity to both antibiotics and bacteriocins of Bacillus thuringiensis was tested. Forty-six milk samples were selected for their positive California Mastitis Test (CMT) ( $\geq 3)$ and any abnormality in the udder or milk. The frequency of SCM and CLM was 39.1\% and 9.3\%, respectively. Averages for test day milk yield (MY), lactation number (LN), herd size (HS), and number of days in milk (DM) were $20.6 \mathrm{~kg}, 2.8$ lactations, 16.7 animals, and 164.1 days, respectively. MY was dependent on dairy herd (DH), LN, HS, and DM $(P<0.01)$, and correlations between udder quarters from the CMT were around $0.49(P<0.01)$. Coagulase-negative staphylococci were mainly identified, as well as Staphylococcus aureus, Streptococcus uberis, Brevibacterium stationis, B. conglomeratum, and Staphylococcus agnetis. Bacterial isolates were resistant to penicillin, clindamycin, ampicillin, and cefotaxime. Bacteriocins synthesized by Bacillus thuringiensis inhibited the growth of multiantibiotic resistance bacteria such as S. agnetis, S. equorum, Streptococcus uberis, Brevibacterium stationis, and Brachybacterium conglomeratum, but they were not active against S. sciuri, a microorganism that showed an $84 \%$ resistance to antibiotics tested in this study.
\end{abstract}

\section{Introduction}

In Mexico, the national milk production has an average annual growth rate of $\sim 1.3 \%$, representing an increase of 9,784 to 10,677 million liters per year during the period from 2003 to 2010 [1]. The backyard livestock is one of the oldest production systems in Mexico; however, the governments have not considered it important enough [2]. In the last few years, family dairy herds or small-scale dairy enterprises contribute to the national milk production with values ranging from 35 to $40 \%$ [3]. Milk is mainly sold locally in different sale channels directly to consumers, or through intermediaries or the rural or commercial industry. Intermediaries collect milk either to supply fluid milk in urban areas or to manufacture traditional cheese that is in remarkable demand in cities or suburban areas $[4,5]$.

According to the Food and Agriculture Organization [6], small herds are a majority in the developing world. In these 
herds, animal health care is scarce because producers carry out neither preventive medicine nor a hygienic handling of milk during milking [4]. Even though mastitis is the largest cause of antimicrobial use in dairy herds $[7,8]$, very little is known about the use of antibiotics in small dairy herds. Mastitis is the inflammation of the mammary gland and it is a complex and costly disease in dairy herds $[9,10]$. Subclinical mastitis (SCM) has a tendency to persist because it usually remains undetected. About 70 to $80 \%$ of the estimated $\$ 140$ to $\$ 300$ dollar loss per cow per year from mastitis relates to decreased milk production caused by asymptomatic subclinical mastitis [11]. The bacterial contamination of milk from the affected cows makes it unhealthy for human consumption and has zoonotic importance [12]. The mastitis occurrence in Mexico has been reported [13, 14], but there are few reports about bovine udder health, including the etiology of intramammary infections (IMI), antimicrobial susceptibility patterns, and mastitis frequency [15].

Alternatively, bacteriocins are antimicrobial peptides ribosomally synthesized by prokaryotes that inhibit or kill phylogenetically related and/or unrelated microorganism that share the same microbial niche. These peptides have a potential for diversified use in different areas such as food, pharmaceutical industries, agriculture, and apiculture $[16,17]$. In particular, bacteriocins produced by Bacillus thuringiensis, the most important microbial insecticide, have showed potential to inhibit Staphylococcus aureus isolates associated with bovine mastitis [18]. Unfortunately, no other bacteria associated with this disease in Mexico have been tested using antimicrobial peptides synthesized by $B$. thuringiensis. In this study, our objective was to isolate and to identify molecularly microorganisms from bovine mastitis, determine antimicrobial susceptibility to antibiotic and bacteriocins synthesized by $B$. thuringiensis, and estimate the frequency of mastitis in family dairy herds from the central region of Mexico.

\section{Material and Methods}

2.1. Study Area and Herds. The study was developed in four municipalities in the state of Guanajuato, Mexico: Abasolo, Cuerámaro, Irapuato, and Silao. This region is located in central Mexico, to the south of the Mexican high plateau. Geographically, there are three climatic zones defined in Guanajuato with a pleasant climate with temperatures ranging from $11.7^{\circ} \mathrm{C}$ to $24.2^{\circ} \mathrm{C}$, an average altitude of 2,015 meters above sea level, and annual average rainfall of $635 \mathrm{~mm}$. Guanajuato is located at west longitude $99^{\circ} 40^{\prime}-102^{\circ} 6^{\prime}$ and north latitude $21^{\circ} 51^{\prime}-19^{\circ} 55^{\prime}$. Thirty-two family dairy herds were included in this study, which were selected for convenience based on the readiness to participate in the research and the existence of productive and reproductive data at the sampling time. All farms included in this study were classified as family dairy herds, according to [19], who report that farms, including the management system and facilities, should be directly served by the owner and family members, as is the case in the present study [20]. Most herds were HolsteinFriesian breed type with different herd sizes, cows with a different number of days in milk, number of calving, age, and level of milk yield.

2.2. Milk Sample Collection. Subclinical mastitis (SCM) was detected by reactive application (Masti test, BIVE, Mexico) to California Mastitis Test (CMT) in all lactation cows, including a total of 535 animals, following the method described by Schalm and Noorlander [21]. The results were interpreted in scores (range 0-4): 0 for no reaction, 1 a trace, 2 a weak positive, 3 a distinct positive, and 4 a strong positive, or in the case of clinical mastitis cases considering visual abnormalities such as flakes, clots, or any color changes in the milk, or by detecting slight swelling of the affected quarter udder. Once the udder quarters affected by subclinical (CMT 3) and clinical (any visual abnormality) mastitis were identified, teats were disinfected with swabs soaked in $70 \%$ ethyl alcohol. After discarding the first few streams, $10-15 \mathrm{~mL}$ milk samples were collected in sterile caped tubes and numbered, according to standard procedures of the National Mastitis Council [22]. Samples were cooled and immediately transported to the Laboratory of Proteomic and Genic Expression of the Life Science Division at the University of Guanajuato, Mexico.

2.3. Microbiological Culture and Isolation. Forty-six milk samples from udder quarters affected by mastitis were sent to microbiological analysis. Each sample was taken in clean conditions and a sown dilution of $1: 10,1: 100$, and $1: 1000$. The dilution was made using PBS buffer $(130 \mathrm{mM} \mathrm{NaCl}$, $10 \mathrm{mM} \mathrm{NaPO}_{4}$, and $\mathrm{pH} 7.2$ ) and then it was added to culture medium with agar as per standard procedures [22]. The different culture media used were Todd-Hewitt, Tryptic Soy Agar, and culture medium containing peptone trypticase, $10 \mathrm{~g} / \mathrm{L}$; yeast extract, $1.0 \mathrm{~g} / \mathrm{L} ; \mathrm{KH}_{2} \mathrm{PO}_{4}, 3.0 \mathrm{~g} / \mathrm{L} ; \mathrm{K}_{2} \mathrm{HPO}_{4}$, $4.8 \mathrm{~g} / \mathrm{L} ;\left(\mathrm{NH}_{4}\right)_{2} \mathrm{SO}_{4}, 30 \mathrm{~g} / \mathrm{L} ; \mathrm{MgSO}_{4} \cdot 7 \mathrm{H}_{2} \mathrm{O}, 0.2 \mathrm{~g} / \mathrm{L} ; \mathrm{L}$-cysteine $\mathrm{HCl} \cdot \mathrm{H}_{2} 0,0.5 \mathrm{~g} / \mathrm{L}$; sodium propionate, $15 \mathrm{~g} / \mathrm{L}$; agar, $15 \mathrm{~g} / \mathrm{L} ; \mathrm{pH}$ $6.0-7.9$, all with the addition of $5 \%$ of sheep blood. The plates were incubated under aerobic conditions at $37^{\circ} \mathrm{C}$ for $72 \mathrm{~h}$. For molecular identification those culture plates with growing of one or two different colonies were included. Culture plates showing the growth of three or more different colonies were discarded and registered as contaminate sample [22]. They also were subcultured in LB liquid at $37^{\circ} \mathrm{C}$ for $72 \mathrm{~h}$, and after this time $20 \%$ glycerol was added. Bacteria stocks were stored at $-80^{\circ} \mathrm{C}$.

2.4. $16 S$ rDNA Amplification. For confirmation of the identity, isolation of genomic DNA was carried out by picking one colony from fresh culture plate. The $16 \mathrm{~S}$ rDNA was amplified by colony-PCR using $10 \mathrm{pM}$ of the universal oligonucleotide set that amplifies both bacterial domains: forward UBF $5^{\prime}$ AGAGTTTGATCCTGGCTGAG-3' and reverse 1492 R5' GGTTACCTTGTTACGACTT- $3^{\prime}$. For the amplification of $16 \mathrm{~S}$ rDNA a proof fidelity enzyme (BioRad) was used under the following conditions: $5 \mathrm{~min}$ at $95^{\circ} \mathrm{C}$; 30 cycles of $30 \mathrm{~s}$ at $95^{\circ} \mathrm{C}, 30 \mathrm{~s}$ at $58^{\circ} \mathrm{C}$, and $1: 30 \mathrm{~min}$ at $72^{\circ} \mathrm{C}$; and finally $5 \mathrm{~min}$ at $72^{\circ} \mathrm{C}$. An aliquot of $5 \mu \mathrm{L}$ of the PCR products was subjected to electrophoresis in $1 \%$ agarose gels and stained with ethidium bromide to visualize the amplified products. The sequencing 
was performed in Molecular Cloning Laboratories (MCLAB; San Francisco, CA, USA). Amplicons were treated for analysis restriction of amplified fragments (ARDRA) with $10 \mathrm{U}$ of enzymes MboI and Bam HI (New England, Bio-Lab UK). The digestion reaction was performed at $37^{\circ} \mathrm{C}$ for $3 \mathrm{~h}$. The digestion products were analyzed in $2 \%$ agarose gels stained with ethidium bromide and digitalized. The amplified fragment from microorganisms that presented different restriction patterns was selected for sequencing. The sequencing was performed in Molecular Cloning Laboratories (MCLAB; San Francisco, CA, USA).

2.5. Bioinformatics Analysis. The ambiguous bases from the $5^{\prime}$ and $3^{\prime}$ terminal sequences were eliminated, and the resulting sequences were confirmed using BioEdit software. Sequences were then compared against the Ribosomal Database Project and GenBank using BLAST against the NCBI nonredundant nucleotide database "nt."

2.6. Antibiotic Susceptibility Testing. For susceptibility testing, isolates were suspended in $5 \mathrm{~mL}$ trypticase soy broth (TSB) at $28^{\circ} \mathrm{C}$ or $37^{\circ} \mathrm{C}$ to a turbidity of 0.5 on a scale of McFarland and with a sterile swab extension covered by the surface of a Petri dish with Muller-Hinton agar gel (MH) (Difco). The antibiotic susceptibility was identified by routine diagnostic methods using standard disk diffusion for Grampositive and Gram-negative (MultiBac I.D., México D.F). Zones of inhibition (in $\mathrm{mm}$ ) were recorder after $\sim 18 \mathrm{~h}$ of incubation at $35-37^{\circ} \mathrm{C}$. The zones of inhibition $(\mathrm{mm})$ were determined and compared with the standards of performance of the supplier to determine whether the tested strain was sensitive (S), intermediate (I), or resistant (R).

2.7. Susceptibility to Antimicrobial Peptides of B. thuringiensis. Mexican strains of $B$. thuringiensis subsp. morrisoni, $B$. thuringiensis subsp. kurstaki, $B$. thuringiensis subsp. kenyae, $B$. thuringiensis subsp. entomocidus, and $B$. thuringiensis subsp. tolworthi produce the bacteriocins Morricin 269, Kurstacin 287, Kenyacin 404, Entomocin 420, and Tolworthcin 524, respectively. These bacteria were cultured at $28^{\circ} \mathrm{C}, 200 \mathrm{rpm}$, for $24 \mathrm{~h}$ in tryptic soy broth (TSB). Extracellular proteins were precipitated with ammonium sulfate to $80 \%$ saturation at $4^{\circ} \mathrm{C}$, resuspended in $100 \mathrm{mM}$ phosphate buffer $(\mathrm{pH} 7.0)$, and dialyzed overnight using a $1 \mathrm{kDa}$ cut-off membrane (Amersham Biosciences) to obtain partially purified bacteriocins. To carry out the well-diffusion assay, indicator bacteria were cultivated overnight in tryptic soy broth (TSB), and $105 \mu \mathrm{L}$ $\left(\sim 1 \times 10^{9}\right.$ cell $\left./ \mathrm{mL}\right)$ of each culture was mixed with $15 \mathrm{~mL}$ of TSB with warm soft agar $0.7 \%(w / v)$ and plated. Five wells of $8 \mathrm{~mm}$ in diameter were dug into the agar and $100 \mu \mathrm{L}$ of partially purified Morricin ( 150 U), Kenyacin ( 260 U), Entomocin ( 260 U), Tolworthcin ( 260 U), and Kurstacin ( $360 \mathrm{U})$, whose inhibitory activities were standardized with Bacillus cereus 183 as indicator bacterium, was added to each well. Then samples were incubated for $12 \mathrm{~h}$ at $4^{\circ} \mathrm{C}$ to allow diffusion of samples, followed by an additional incubation at $28^{\circ} \mathrm{C}$ or $37^{\circ} \mathrm{C}$ for 1 day before diameters of zones of inhibition were measured. The minimum detectable zone measured for analytic purposes was $1 \mathrm{~mm}$ beyond the well diameter. One unit (U) of bacteriocin activity was defined as equal to $1 \mathrm{~mm}^{2}$ of the zone of inhibition of growth of the target indicator bacterium [17, 18, 21]. Additionally, the inhibitory effect of bacteriocins against bacteria was also performed using gel-screening assay. Partial purified bacteriocins in Laemmli's buffer without $\beta$-mercaptoethanol were loaded in two continuous sodium dodecyl sulfate(SDS-) polyacrylamide gels for electrophoresis (SDS-PAGE). One gel was stained with Coomassie blue and the other was fixed in $25 \%(\mathrm{v} / \mathrm{v})$ isopropanol and $10 \%(\mathrm{v} / \mathrm{v})$ acetic acid. The gel was washed with double-distilled water and equilibrated in phosphate buffer $(\mathrm{pH}$ 6.5). The gel was overlaid with TSB with soft agar $0.7 \%(\mathrm{w} / \mathrm{v})$ containing $\sim 1 \times 10^{9} \mathrm{cell} / \mathrm{mL}$ of indicator bacteria and incubated at $28^{\circ} \mathrm{C}$. The next day zones of inhibition were examined and molecular mass of the bacteriocins was calculated [17].

2.8. Data and Statistical Analyses. Data registered in the herds were entered into a spreadsheet in electronic format with Excel for Windows and edited to guarantee the quality of analyses. The dependent variables studied were the test day milk yield in kg (MY) and CMT results by udder quarter. Independent variables were lactation number (LN), family dairy herd (DH), herd size (HS), number of days in milk (DM), and municipality (M). Descriptive analysis was used for the variables included in this study. Normality was evaluated for the dependent variables to define the type of statistical analysis. The variables were recorded and grouped into the next categories: HS ( $0-15,16-25$, and $>25$ cows), LN $(1,2,3$, and $>4)$, and DM (0-90, 91-180, and >180 days). In order to know the independence between some variables and because most of these were discrete and without normal distribution, the chi-square test was applied between MY, DH, HS, LN, and DM. To estimate the probability of association between results of CMT, udder quarters were estimated using the Spearman rank correlation. For the statistical analyses, the Statgraphics Centurion program version 15.2 was used.

\section{Results and Discussion}

3.1. Characteristics and Parameters of Dairy Farms. Table 1 shows the variability among farms according to the herd size (from 3 to 47 heads), number of lactations (from 1.7 to 4.1 lactations), number of days in milk (from 52 to 275 days), and average of test day milk yield (from 9.0 to $26.4 \mathrm{Kg}$ ). The family dairy herds are one of the dominant and widely distributed production systems in Mexico, in small scale units run by the family. It was estimated that $10 \%$ of all milk production in Mexico comes from family dairy herds. According to the livestock census carried out in 2007, it was found that $\sim 73 \%$ of units correspond to the small farms [4]. It is interesting that although in Mexico a decrement in the family dairy participation has been reported to domestic supplies it has been observed that it does not have a direct influence on the number of small farms as it remains without important changes. The herd size of the family farms reported in this study is much lower than suggested from family 
TABLE 1: Descriptive statistics for variables studied from family dairy herds $(n=32)$ from the central region of Mexico.

\begin{tabular}{lcccc}
\hline Parameter & Mean & $\begin{array}{c}\text { Standard } \\
\text { deviation }\end{array}$ & Minimum & Maximum \\
\hline Herd size (heads) & 16.7 & 9.4 & 3 & 47 \\
Days in milk & 161.4 & 108.2 & 7 & 730 \\
Lactation number & 2.8 & 1.6 & 1 & 16 \\
Milk yield (Kg) & 20.6 & 7.2 & 3 & 45 \\
\hline
\end{tabular}

dairy farms in Los Altos, Jalisco, Mexico, where an average population of 61 lactating cows was described. However, the average of milk yield per cow obtained in this study $(20.6 \mathrm{~L} / \mathrm{d})$ was higher than $17.8 \mathrm{~L} / \mathrm{d}$ (Jalisco) [23] and $11.4 \mathrm{~L} / \mathrm{d}$ (Jalisco and Michoacán) [24]. As indicated above, of all the dairy production systems in Mexico, the familial system is the most heterogeneous. The farms that compose this system range from subsistence operations (milk and cheese are used exclusively to feed the family) to large-scale operations (milk sale is the primary but not the unique source of income for the family). The family production system is centered in the west central region of the country, including the states of Jalisco, Michoacán, Aguascalientes, and Guanajuato [23].

3.2. Frequencies of Subclinical and Clinical Bovine Mastitis. CMT global results in this study showed that $48 \%$ of animals $(n=257)$ were negative, and $52 \%$ of animals $(n=278)$ showed a positive reaction to SCM. However, SCM per animal among herds ranged from 11 to $75 \%$. Concerning the quarter reaction degree of CMT, milk samples registered a $10.3 \%$ (trace), $6.12 \%$ (grade 1), 2.9\% (grade 2), 5.28\% (grade 3 ), and $1.59 \%$ dry-off gland, and the remaining percentage was negative $(72.2 \%)$. In general, at least one case of clinical mastitis was detected in $66 \%$ of the dairy herds studied (21 of 32). The percentage of CLM per animal among herds ranged from 0 to 25 (Table 2 ). In small-scale dairy herds, hygiene and health management are often poor, a situation that contributes to the development of clinical mastitis cases [13]. This might explain the higher prevalence of CLM registered in this study (0-25\%), especially when datum is compared with the results obtained in family dairy herds from State of Mexico (3.4-9.8\%) [13] and also with Jalisco $(4.0 \%)$ [25]. Furthermore, it is necessary to consider that there is a clear variation in the epidemiology of mastitis and mastitis inducers among different regions in Mexico [25]. The frequency of clinical cases based on quarter udder signs was $78 \%$ (25/32), moderately acute; $16 \%(5 / 32)$, chronic; and $6.2 \%(2 / 32)$, severe acute. Statistical analysis showed that MY was dependent on the farm, HS, DIM, and LN $(P<$ 0.01 ) (Table 3 ). The estimated correlation between results of CMT for each udder quarter ranged from 0.46 to 0.52 $(P<0.01)$. Mastitis is an expensive disease, where a high proportion of dairy farms might have avoidable losses [26]. The frequency of SCM obtained in our study (11-75\%) was as high as that obtained (23-52\%) in dairy cattle located in province of Huaral, Lima, Peru [27]. In addition, our data are comparable with two studies carried out in smallholder
TABLE 2: Frequency of subclinical (SCM) and clinical (CLM) mastitis in family dairy herds from the central region of Mexico.

\begin{tabular}{|c|c|c|}
\hline \multicolumn{3}{|c|}{ Frequency $(\%)^{*}$} \\
\hline Farm & SCM & CLM \\
\hline 1 & $4 / 12(33)$ & $1 / 12(8)$ \\
\hline 2 & $0 / 3(0)$ & $0 / 3(0)$ \\
\hline 3 & $4 / 8(50)$ & $2 / 8(25)$ \\
\hline 4 & $8 / 14(57)$ & $2 / 14(14)$ \\
\hline 5 & $4 / 9(44)$ & $0 / 9(0)$ \\
\hline 6 & $5 / 9(56)$ & $0 / 9(0)$ \\
\hline 7 & $3 / 14(21)$ & $0 / 14(0)$ \\
\hline 8 & $5 / 17(29)$ & $0 / 17(0)$ \\
\hline 9 & $10 / 16(63)$ & $1 / 16(6)$ \\
\hline 10 & $5 / 10(50)$ & $0 / 10(0)$ \\
\hline 11 & $9 / 26(35)$ & $2 / 26(8)$ \\
\hline 12 & $6 / 16(38)$ & $0 / 16(0)$ \\
\hline 13 & 3/11 (27) & $0 / 11(0)$ \\
\hline 14 & 9/12 (75) & $3 / 12(25)$ \\
\hline 15 & $13 / 28(46)$ & $6 / 28(21)$ \\
\hline 16 & $7 / 13(54)$ & $2 / 13(15)$ \\
\hline 17 & $19 / 31(61)$ & $6 / 31(19)$ \\
\hline 18 & 2/12 (17) & $2 / 12(17)$ \\
\hline 19 & 3/19 (16) & $1 / 19(5)$ \\
\hline 20 & $8 / 20(40)$ & $3 / 20(15)$ \\
\hline 21 & 8/47 (17) & 9/47 (19) \\
\hline 22 & $17 / 36(47)$ & $4 / 36(11)$ \\
\hline 23 & 2/18 (11) & $4 / 18(22)$ \\
\hline 24 & $18 / 29(62)$ & $0 / 29(0)$ \\
\hline 25 & $3 / 12(25)$ & $1 / 12(8)$ \\
\hline 26 & $7 / 15(47)$ & $2 / 15(13)$ \\
\hline 27 & $5 / 9(56)$ & $0 / 9(0)$ \\
\hline 28 & $10 / 16(63)$ & $2 / 16(13)$ \\
\hline 29 & 3/9 (33) & 1/9 (11) \\
\hline 30 & 4/24 (17) & $4 / 24(17)$ \\
\hline 31 & $3 / 6(50)$ & $0 / 6(0)$ \\
\hline 32 & 2/14 (14) & $1 / 14(7)$ \\
\hline
\end{tabular}

TABLE 3: Results of the chi-square independence test between different variables.

\begin{tabular}{lcc}
\hline Variables & Statistical values & Probability \\
\hline Milk yield-herd & 1684.197 & 0.0000 \\
Milk yield-herd size & 1706.651 & 0.0064 \\
Milk yield-days in milk & 2548.930 & 0.0000 \\
Milk yield-lactation number & 533.235 & 0.0000 \\
\hline
\end{tabular}

and/or family dairy farms located in the Jalisco and State of Mexico, Mexico, where SCM prevalence per animal was of 34.1 and $48.3 \%$, respectively $[13,25]$. It is important to indicate that both SCM and CLM were associated with herd size, parity, management practices, and time of lactation [25]. The prevalence of mastitis might change between countries and geographical regions, but frequently the highest prevalence is 
TABle 4: Potential microbial pathogens isolated from dairy cattle and their susceptibility to antibiotics ${ }^{\mathrm{a}}$.

\begin{tabular}{|c|c|c|c|c|c|c|c|c|c|c|c|c|c|}
\hline Bacteria & Accession number & & & & & & Antil & biotics $^{b}$ & & & & & \\
\hline Gram-positive & & $\mathrm{E}$ & $\mathrm{PE}$ & $\mathrm{TE}$ & AM & CFX & $\mathrm{CPF}$ & CLM & SXT & VA & $\mathrm{CF}$ & DC & GE \\
\hline Staphylococcus aureus & KP224443 & $S$ & $\mathrm{R}$ & $S$ & $\mathrm{R}$ & $\mathrm{R}$ & $S$ & $\mathrm{R}$ & S & $S$ & $\mathrm{~S}$ & S & $S$ \\
\hline Staphylococcus agnetis & JQ394696 & S & $\mathrm{R}$ & S & $\mathrm{R}$ & $\mathrm{R}$ & S & $\mathrm{R}$ & S & S & S & S & S \\
\hline Staphylococcus epidermidis & KP224442 & $S$ & $\mathrm{R}$ & $S$ & I & $\mathrm{R}$ & $S$ & $\mathrm{R}$ & S & $S$ & $S$ & $S$ & S \\
\hline Staphylococcus sciuri & KP224448 & I & $\mathrm{R}$ & I & $\mathrm{R}$ & $\mathrm{R}$ & $\mathrm{R}$ & $\mathrm{R}$ & $\mathrm{R}$ & $\mathrm{R}$ & $\mathrm{R}$ & $\mathrm{R}$ & $\mathrm{R}$ \\
\hline Staphylococcus haemolyticus & KP224444 & S & $\mathrm{R}$ & $S$ & $\mathrm{R}$ & $\mathrm{R}$ & $S$ & $\mathrm{R}$ & S & S & $S$ & $S$ & $S$ \\
\hline Staphylococcus equorum & KP224447 & S & $\mathrm{R}$ & S & $\mathrm{R}$ & $S$ & S & I & S & S & S & S & S \\
\hline Streptococcus dysgalactiae & KP224445 & S & $\mathrm{R}$ & S & $\mathrm{R}$ & $\mathrm{R}$ & S & $\mathrm{R}$ & S & S & S & S & S \\
\hline Streptococcus uberis & KP224446 & S & I & S & $\mathrm{R}$ & S & S & I & S & S & $\mathrm{R}$ & S & S \\
\hline Brevibacterium stationis & KP224449 & I & $\mathrm{R}$ & S & I & I & S & $\mathrm{R}$ & S & S & S & S & S \\
\hline Brachybacterium conglomeratum (1) cvbnm & KP224450 & S & $\mathrm{R}$ & I & S & $\mathrm{R}$ & $S$ & $\mathrm{R}$ & $S$ & $S$ & $S$ & $S$ & S \\
\hline Gram-negative & & CL & $\mathrm{AK}$ & $\mathrm{CB}$ & NET & NF & NOF & CF & $\mathrm{AM}$ & CFX & $\mathrm{CPF}$ & SXT & GE \\
\hline Raoultella sp. & KP224451 & $\mathrm{S}$ & $\mathrm{S}$ & $\mathrm{R}$ & $\mathrm{S}$ & $\mathrm{I}$ & $S$ & $\mathrm{R}$ & $\mathrm{R}$ & $\mathrm{S}$ & $\mathrm{S}$ & $S$ & $S$ \\
\hline
\end{tabular}

${ }^{\mathrm{a}} \mathrm{R}$, resistant; $\mathrm{S}$, susceptible; I, intermediate.

${ }^{b}$ Erythromycin (E), penicillin (PE), tetracycline (TE), ampicillin (AM), cefotaxime (CFX), ciprofloxacin (CPF), clindamycin (CLM), sulfamethoxazoletrimethoprim (SXT), vancomycin (VA), cephalothin (CF), dicloxacillin (DC), gentamicin (GE), amikacin (AK), carbenicillin (CB), chloramphenicol (CL), netilmicin (NET), nitrofurantoin (NF), and norfloxacin (NOF).

found in countries with a poorly developed dairy sector and with a lack of udder health control programs.

3.3. Isolation and Bacterial Identification. A total of eleven milk samples plated (24\%) were selected for bacterial isolation and identification. The remaining milk samples plated were not considered for showing a lack of growth or a contaminated bacteria growth. It is necessary to highlight that most of the milk samples of this study were from SCM cases, where (i) the colony-forming units of the organism in the milk were below the detection limit of the assay, (ii) special media or growth conditions were required, or (iii) presence of inhibitors in the milk sample, such as antibiotics, had interfered with the growth of the pathogen. If it is common that $20-30 \%$ of clinical quarters will result in no microbial growth, this percentage could be increased when milk samples come from SCM as in this study. Also, clinical signs could be present but the pathogen might be eliminated or controlled by the cow's immune system [22]. Bacterial PCR amplification and subsequent ARDRA analyses of 16S rDNA gene were successful for all samples. The 16S rDNA sequences that presented different ARDRA profiles were selected for sequencing (Table 4). Five genera and eleven bacterial species involved in cases of mastitis were identified. Table 4 shows that $42 \%$ of the isolated microorganisms were coagulase-negative staphylococci (CNS). Similar results were obtained in smallholder dairy farms from Jalisco state of Mexico, where the most common udder pathogens were CNS (15.6\%), followed by S. aureus (5.9\%), S. agalactiae (6.8\%), Corynebacterium spp. (14\%), and coliform bacteria (4.1\%) [25]. CNS are considered minor pathogens, especially in comparison with major pathogens such as $S$. aureus, streptococci, and coliforms [28]. However, these bacteria are of great interest because they are regularly isolated from milk samples obtained from cows and are currently considered emerging pathogens of bovine mastitis and the main cause of intramammary infection (IMI) in modern dairy herds [2931].

Alternatively, a total of 124 milk samples were collected from 124 multiparous lactating dairy (Holstein) cows at the province of Nanning, China. Positive CMT was recorded from $65(52.4 \%)$ glands. Bacteria were isolated from 45 (36.3\%) of milk samples. Distributions of microbial isolates responsible for infected milk samples have been reported as follows: S. aureus (47\%), CNS (27\%), Escherichia coli (9\%), S. agalactiae (9\%), S. uberis (4\%), and Cryptococcus neoformans (4\%) [32]. In another study, Lago et al. [33] found 422 cows affected by clinical mastitis in 449 quarters, where coliform bacteria were the most commonly isolated pathogen (24\% of clinical mastitis cases).

According to results of sequence analysis of isolates conducted in the present study (retrieved from the GenBank, http://www.ncbi.nlm.nih.gov/, using the nucleotidenucleotide BLAST algorithm) Staphylococcus agnetis (NCBI/ EMBL accession JQ 394696) was isolated from milk samples of mastitis cases. It is important to emphasize that $S$. agnetis is mentioned only once before in the literature as a pathogen causing mastitis in dairy cattle. Recently, it has been reported that $S$. agnetis was associated with bovine mastitis based on the characteristics of 12 isolates originating from milk samples of cows with subclinical or mild clinical IMI and one isolate from the apex of the teat [34]. We also identified the bacteria Brevibacterium stationis and Brachybacterium conglomeratum. Although these microorganisms have not been reported as etiological agents of cow mastitis, they have occasionally been isolated from goat raw milk samples and also from different areas of the farm (e.g., teat surfaces, milking parlors, hay, air, and dust) [35].

3.4. Antibiotic Susceptibility Patterns. Six isolates of this study (54.54\%) showed resistance to two or three antimicrobial agents, mostly to penicillin, clindamycin, and cefotaxime; 


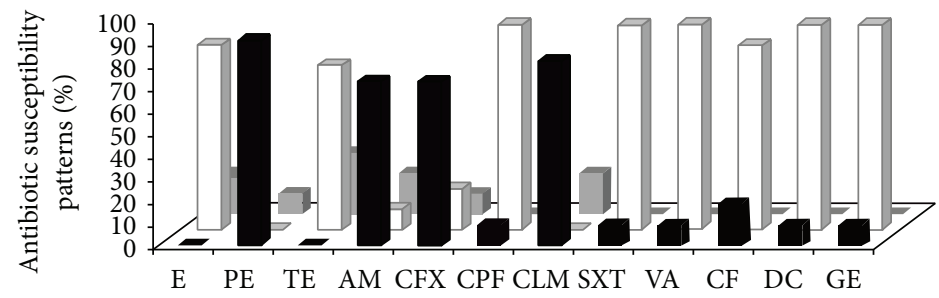

Figure 1: Percentage of sensitivity in vitro by standard disk diffusion (MultiBac-ID) of different antibiotics against bacterial isolates from bovine mastitis. Graphic bars represent the percentage of sensitive (white), intermediate (grey), or resistant (black). Erythromycin (E), penicillin (PE), tetracycline (TE), ampicillin (AM), cefotaxime (CFX), ciprofloxacin (CPF), clindamycin (CLM), sulfamethoxazoletrimethoprim (SXT), vancomycin (VA), cephalothin (CF), dicloxacillin (DC), and gentamicin (GE).

meanwhile resistance to four or more antimicrobial agents was found in 5 isolates $(45.45 \%)$. All isolates showed a variable susceptibility ( $60 \%)$ to the 12 antimicrobials tested. Special consideration showed Staphylococcus sciuri isolated that was resistant to 10 of 12 antimicrobials tested and the rest were detected with intermediate susceptibility (Table 4 ). The microorganisms were mainly resistant to penicillin (90\%), clindamycin and cefotaxime (both 80\%), and ampicillin (70\%). In this study we found a high frequency of penicillinresistant bacteria, which is higher than those reported in subclinical milk samples obtained from dairy herds located in state of Michoacán, Mexico (74\%) [18]. In addition, percentage of ampicillin-resistant microorganisms (i.e., 70\%) was very similar to that reported $(67.4 \%)$ in a study performed in dairy herds of south of Brazil [36]. In particular, in Mexico it is very common that, at the end of period of lactation in dairy cattle, farmers use a prophylactic dose of antimicrobial (i.e., penicillins and cephalosporins) into the udder. Although the purpose of this treatment is the prevention of future mastitis, it is obvious that this procedure might generate penicillin-resistant microorganisms [37]. In addition, some isolates were highly sensitive (90\%) to trimethoprim/sulfamethoxazole, dicloxacillin, ciprofloxacin, and gentamicin (Figure 1). All microorganisms shown in Table 4 were identified as Gram-positive bacteria. Only one Gram-negative microorganism was isolated and identified as Raoultella sp., which had resistance to ampicillin, carbenicillin, and cephalothin. Raoultella sp. (before Klebsiella sp.) is one of the most frequent Gram-negative pathogens isolated from bovine clinical mastitis [38]; and it has been isolated from bedding material [39].

The emergence of antimicrobial resistance among pathogens that affect animal health is a growing concern in veterinary medicine. Furthermore, the use of antimicrobial drugs has also been considered as a potential health risk for humans [40, 41]. S. agnetis showed resistance (33.0\%) to penicillin, ampicillin, cefotaxime, and clindamycin (Table 4). It should be noted that, in another study, $S$. agnetis was resistant to lysozyme, polymyxins, and deferoxamine, and it was susceptible to novobiocin and lysostaphin [34]. Phylogenetically, S. agnetis is a novel species of the genus Staphylococci and can be differentiated from the coagulasepositive species, such as S. hyicus, S. simulans, S. schleiferi,
S. chromogenes, S. intermedius, and S. epidermidis. Compared to $S$. aureus, streptococci, and coliforms, coagulase-negative staphylococcus (CNS) has been considered an emerging bovine mastitis pathogen in several countries [30, 42, 43] with a high degree of resistance to some conventional drugs [30, 40, 43, 44]. CNS mastitis responds much better to antimicrobial treatment than $S$. aureus mastitis, but resistance to different antimicrobials is more common in CNS than S. aureus. CNS tends to be more resistant to antimicrobials than $S$. aureus and can easily develop multiresistance. The most common resistance mechanism in staphylococci is $\beta$-lactamase production, which results in resistance to penicillin $\mathrm{G}$ and aminopenicillin [28].

3.5. Inhibitory Activity of Bacteriocins. We recently showed that antimicrobial peptides or bacteriocins (Morricin 269, Kurstacin 287, Kenyacin 404, Entomocin 420, and Tolworthcin 524) synthesized by $B$. thuringiensis are able to inhibit food-borne pathogenic bacteria [17]. In addition it was demonstrated that Staphylococcus strains isolated from bovine with mastitis are also susceptible to this kind of bacteriocins [18]. In the present study the five bacteriocins inhibited the growth of $S$. agnetis, S. equorum, Streptococcus uberis, B. stationis, and B. conglomeratum, bacteria that showed multiantibiotic resistance (Table 5). Unfortunately, bacteriocins did not show activity on S. sciuri, microorganism with an $84 \%$ resistance to antibiotics tested in this study. This bacterium has been found to be associated not only with bovine subclinical mastitis [45], but also with serious infections in humans such as endocarditis [46], peritonitis [47], wound infections [48], and urinary infections [49]. In addition, we did not find susceptibility of $S$. aureus to the bacteriocins, which is very interesting as we previously demonstrate that different isolates of this bacterium are susceptible to the five antimicrobial peptides tested in this work [18]. We do not have a clear explanation for this observation, but it has been shown that, within the same genus or strains of the same species, microorganisms can differ in their susceptibilities to a particular bacteriocin. For example, (i) B. licheniformis strain P40 produces an antimicrobial peptide with inhibitory action to $S$. intermedius but not to $S$. aureus [50]. (ii) Also, S. aureus strains isolated from dairy cow mastitis [18] showed different susceptibilities 
TABLE 5: Inhibitory activity $\left(\mathrm{U}^{\mathrm{a}}\right)$ of partial purified bacteriocin determined by the well-diffusion method against potential microbial pathogens associated with mastitis in dairy bovines.

\begin{tabular}{|c|c|c|c|c|c|}
\hline \multirow{2}{*}{ Indicator bacteria } & \multicolumn{5}{|c|}{ Bacteriocins } \\
\hline & Morricin 269 & Kurstacin 287 & Kenyacin 404 & Entomocin 420 & Tolworthcin 524 \\
\hline Bacillus cereus $183^{\mathrm{b}}$ & 151 & 365 & 264 & 264 & 264 \\
\hline Staphylococcus aureus & 0 & 0 & 0 & 0 & 0 \\
\hline Streptococcus dysgalactiae & 0 & 0 & 365 & 365 & 330 \\
\hline Staphylococcus agnetis & 53 & 28 & 142 & 148 & 104 \\
\hline Staphylococcus epidermidis & 0 & 0 & 0 & 0 & 0 \\
\hline Streptococcus uberis & 204 & 296 & 264 & 296 & 233 \\
\hline Staphylococcus sciuri & 0 & 0 & 0 & 0 & 0 \\
\hline Staphylococcus haemolyticus & 0 & 0 & 0 & 0 & 0 \\
\hline Staphylococcus equorum & 186 & 245 & 231 & 374 & 225 \\
\hline Brevibacterium stationis & 62 & 28 & 329 & 204 & 150 \\
\hline Brachybacterium conglomeratum & 103 & 44 & 296 & 480 & 150 \\
\hline Raoultella sp. & 264 & 264 & 296 & 296 & 264 \\
\hline
\end{tabular}

${ }^{\mathrm{a}}$ One unit is defined as $1 \mathrm{~mm}^{2}$ of the zone of inhibition as determined by the well-diffusion method (see text). Data are the average of triplicate assays. A value of "0" indicates no inhibition.

${ }^{\mathrm{b}}$ Bacterium used as positive control. It was used to determine the units of bacteriocins contained in the crude extracts used in the assay [17, 18].

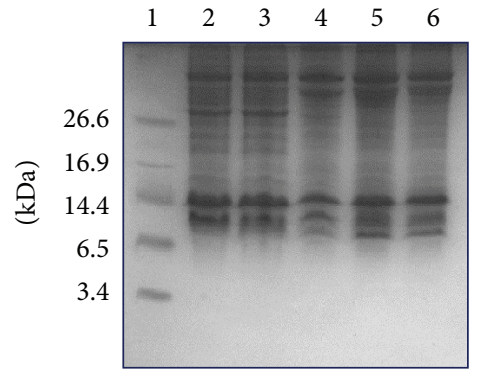

(a)

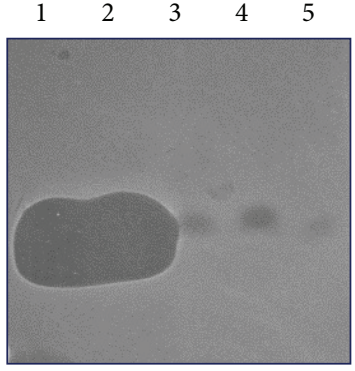

(b)

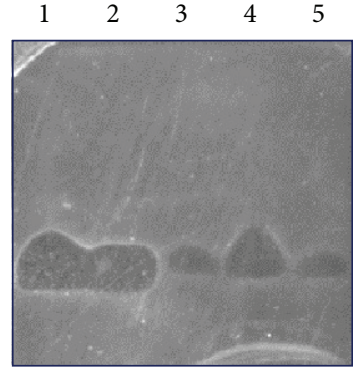

(c)

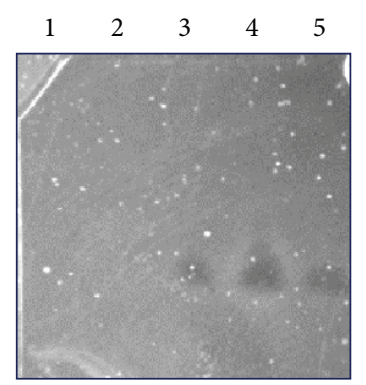

(d)

FIGURE 2: Inhibitory detection of bacteriocins against bacteria using gel-screening assay. (a) SDS-PAGE; gel was overlaid with (b) Bacillus cereus 183 (control), (c) Raoultella sp., and (d) Staphylococcus agnetis. Bacteria (c) and (d) were isolated from bovines with mastitis. Lane 1, Morricin 269; lane 2, Kurstacin 287; lane 3, Kenyacin 404; lane 4, Entomocin 420; lane 5, Tolworthcin 524. Growth inhibition zones show the relative position of bacteriocins with molecular mass of $\sim 10 \mathrm{kDa}$. Protein marker (BioRad) was used to estimate the molecular masses of bacteriocins.

to the five bacteriocins used in this study. In addition, it seems that pathogenic microorganisms have acquired the ability to sense and to respond to bacteriocins in different way, often resulting in reduced negative charge of their cell envelope due to specific surface modifications, which in consequence induce the generation of bacteriocin-resistant bacteria [51].

Alternatively, in order to detect the molecular mass of the bacteriocins, we carried out gel-screening assays using Raoultella sp. and S. agnetis as reporter bacteria. Morricin 269, Kurstacin 287, Kenyacin 404, Entomocin 420, and Tolworthcin 524 exhibited molecular mass of $\sim 10 \mathrm{kDa}$ as shown previously (Figure 2) [17]. It is important to indicate that because we used different units of bacteriocins, we did not carry out comparisons in the inhibitory effects of the different bacteriocins against the bacteria assayed in this work, as our purpose was only to detect whether microorganisms were susceptible or not to the antimicrobial peptides.

\section{Conclusions}

In this work, the most common udder pathogens isolated from mastitis milk samples were coagulase-negative staphylococci (42\%), followed by streptococci (17\%), and S. aureus, B. stationis, B. conglomeratum, and Raoultella sp. with an $8 \%$ each. We found that $72.7 \%$ of isolates had a resistance pattern to three or more antimicrobial agents mainly to penicillin, clindamycin, and cefotaxime. Studies on the prevalence rate of clinical and subclinical mastitis of different mastitis pathogens in a cow population from small-scale dairy herds are scarce. Although it is difficult to compare results obtained in this work with those obtained in other countries, CNS, $S$. aureus, and streptococci have been reported to be the most prevalent pathogens $[52,53]$. Alternatively, bacteriocins of $B$. thuringiensis inhibited the growth of different bacteria tested here and they could have a viable potential for use 
in integrated management programs to control or prevent mastitis in animals. However, it is obvious that a higher number of bacterial isolates with different genus or different strains of the same genera and species obtained from bovine mastitis must be tested in future studies.

\section{Conflict of Interests}

The authors declare that they have no conflict of interests regarding the publication of this paper.

\section{Acknowledgments}

This research was supported by Grants from SEP-PROMEP (103.5/10/4684) and University of Guanajuato, Mexico (Project 262/2013), to Abner J. Gutierrez-Chavez and J. E. Barboza-Corona, respectively. The authors also appreciate the support received from the Fundación Guanajuato Produce AC for the development of this research through the FGP 583/ 12 Project. E. A. Martínez-Ortega is an undergraduate student supported by the Universidad de Guanajuato. They thank Dr. Luz Edith Casados-Vázquez and Jaime J. Badajoz-Martínez from the Universidad de Guanajuato for their technical support during this study. They appreciate the contribution of the producers to this study as well.

\section{References}

[1] Secretaria de Economia (SE), Analisis de Sector Lacteo en Mexico, Direccion General de Industrias Basicas, Secretaria de Economia, Mexico City, Mexico, 2012.

[2] R. E. Caceido-Rivas, J. L. Garita-Goiz, and N. M. Paz-Calderon, "Salud animal de una cuenca lechera bajo el sistema de traspatio, Puebla, Mexico," Actas Iberoamericanas de Conservacion Animal, vol. 1, pp. 323-326, 2011.

[3] O. Val-Arreola, E. Kebreab, and J. France, "Modeling small-scale dairy farms in central Mexico using multi-criteria programming," Journal of Dairy Science, vol. 89, no. 5, pp. 1662-1672, 2006.

[4] R. Jiménez-Jiménez, V. Espinosa-Ortiz, F. Alonso-Pesado et al., "Globalization effects in family farms: a case of Mexican dairy production," in The Economic Geography of Globalization, P. Pachura, Ed., InTech, Rijeka, Croatia, 2011.

[5] G. Álvarez-Fuentes, J. G. Herrera-Haro, G. Alonso-Bastida, and A. Barreras-Serrano, "Raw milk quality produced in small dairy farms in the South of Mexico City," Archivos de Medicina Veterinaria, vol. 44, no. 3, pp. 237-242, 2012.

[6] Food Agriculture Organization (FAO), "Status of and prospects for smallholder milk production-a global perspective," in ProPoor Live-stock Policy Initiative, T. Hemme and J. Otte, Eds., Food Agriculture Organization, Rome, Italy, 2010.

[7] J. S. Moon, A. R. Lee, H. M. Kang et al., "Antibiogram and coagulase diversity in staphylococcal enterotoxin-producing Staphylococcus aureus from bovine mastitis," Journal of Dairy Science, vol. 90, no. 4, pp. 1716-1724, 2007.

[8] S. P. Oliver, S. E. Murinda, and B. M. Jayarao, "Impact of antibiotic use in adult dairy cows on antimicrobial resistance of veterinary and human pathogens: a comprehensive review," Foodborne Pathogens and Disease, vol. 8, no. 3, pp. 337-355, 2011.
[9] R. Hussain, M. T. Javed, and A. Khan, "Changes in some bio chemical parameters and somatic cell counts in the milk of buffalo and cattle suffering from mastitis," Pakistan Veterinary Journal, vol. 32, no. 3, pp. 418-421, 2012.

[10] S. Atasever, "Estimation of correlation between somatic cell count and coagulation score of bovine milk," International Journal of Agriculture and Biology, vol. 14, no. 2, pp. 315-317, 2012.

[11] G. Leitner, U. Merin, and N. Silanikove, "Effects of glandular bacterial infection and stage of lactation on milk clotting parameters: Comparison among cows, goats and sheep," International Dairy Journal, vol. 21, no. 4, pp. 279-285, 2011.

[12] A. Sharif, M. Umer, and G. Muhammad, "Mastitis control in dairy production," Journal of Agriculture and Social Science, vol. 5, pp. 102-105, 2009.

[13] A. M. M. López, S. D. Zarco, F. S. García et al., “Staphylococcus aureus biotypes in cows presenting subclinical mastitis from family dairy herds in the central-eastern state of Mexico," Revista Mexicana De Ciencias Pecuarias, vol. 3, no. 2, pp. 265274, 2012.

[14] H. Castañeda Vázquez, S. Jäger, W. Wolter, M. Zschöck, M. A. Castañeda Vazquez, and A. El-Sayed, "Isolation and identification of main mastitis pathogens in mexico," Arquivo Brasileiro de Medicina Veterinaria e Zootecnia, vol. 65, no. 2, pp. 377-382, 2013.

[15] R. E. Miranda-Morales, V. Rojas-Trejo, R. Segura-Candelas et al., "Prevalence of pathogens associated with bovine mastitis in bulk tank milk in Mexico," Annals of the New York Academy of Sciences, vol. 1149, pp. 300-302, 2008.

[16] N. M. de la Fuente-Salcido, L. E. Casados-Vázquez, and J. E. Barboza-Corona, "Bacteriocins of Bacillus thuringiensis can expand the potential of this bacterium to other areas rather than limit its use only as microbial insecticide," Canadian Journal of Microbiology, vol. 59, no. 8, pp. 515-522, 2013.

[17] J. E. Barboza-Corona, H. Vázquez-Acosta, D. K. Bideshi, and R. Salcedo-Hernández, "Bacteriocin-like inhibitor substances produced by Mexican strains of Bacillus thuringiensis," Archives of Microbiology, vol. 187, no. 2, pp. 117-126, 2007.

[18] J. E. Barboza-Corona, N. de la Fuente-Salcido, N. AlvaMurillo, A. Ochoa-Zarzosa, and J. E. López-Meza, "Activity of bacteriocins synthesized by Bacillus thuringiensis against Staphylococcus aureus isolates associated to bovine mastitis," Veterinary Microbiology, vol. 138, no. 1-2, pp. 179-183, 2009.

[19] A. L. Villamar and C. E. Olivera, Situación Actual y Perspectiva de la Producción de Leche de Bovino en México, Coordinación General de Ganadería. Secretaría de Agricultura, Ganadería, Desarrollo Rural, Pesca y Alimentación, Mexico City, Mexico, 2005.

[20] R. G. Sanchez and V. A. Sanchez, La Ganadería Bovina del Estado de Michoacán, Fundación PRODUCE Michoacán, 2nd edition, 2005.

[21] O. Schalm and D. Noorlander, "Experiments and observations leading to the development of California mastitis test," Journal of the American Veterinary Medical Association, vol. 130, no. 5, pp. 199-204, 1957.

[22] J. S. Hogan, R. N. Gonzales, R. J. Harmon et al., Laboratory Handbook on Bovine Mastitis, National Mastitis Council, Madison, Wis, USA, 2009.

[23] M. Wattiaux, J. Blazek, and J. J. Olmos-Colmenero, Bird's Eye View of the Mexican Dairy Industry and On-the-Ground Assessment of Production Systems in the Highlands (Los Altos) 
of Jalisco, Mexico, The Babcock Institute, Madison, Wis, USA, 2012.

[24] L. C. J. Castro, G. R. Sánchez, L. F. E. Iruegas et al., "Tendencias y oportunidades de desarrollo de la red de leche en Mexico," Boletin Informativo, vol. 133, no. 317, pp. 1-135, 2001.

[25] H. C. Vázquez, S. Jäger, W. Wolter, M. Zschöck, M. A. C. Vazquez, and A. El-Sayed, "Isolation and identification of main mastitis pathogens in mexico," Arquivo Brasileiro de Medicina Veterinaria e Zootecnia, vol. 65, no. 2, pp. 377-382, 2013.

[26] H. Hogeveen, K. Huijps, and T. J. G. M. Lam, "Economic aspects of mastitis: new developments," New Zealand Veterinary Journal, vol. 59, no. 1, pp. 16-23, 2011.

[27] C. Velasquez and J. Vega, "Milk quality and subclinical mastitis in dairy herds in the province of huaura, Lima-Peru," Revista de Investigaciones Veterinarias del Peru, vol. 23, no. 1, pp. 65-71, 2012.

[28] S. Taponen and S. Pyörälä, "Coagulase-negative staphylococci as cause of bovine mastitis-Not so different from Staphylococcus aureus?" Veterinary Microbiology, vol. 134, no. 1-2, pp. 29-36, 2009.

[29] K. L. Smith and J. S. Hogan, "The world of mastitis," in Proceedings of the 2nd International Symposium on Mastitis and Milk Quality, pp. 1-12, Vancouver, Canada, 2001.

[30] Y. H. Schukken, R. N. González, L. L. Tikofsky et al., "CNS mastitis: nothing to worry about?” Veterinary Microbiology, vol. 134, no. 1-2, pp. 9-14, 2009.

[31] S. Pyörälä and S. Taponen, "Coagulase-negative staphylococci-emerging mastitis pathogens," Veterinary Microbiology, vol. 134, no. 1-2, pp. 3-8, 2009.

[32] F. L. Yang, X. S. Li, B. X. He et al., "Malondialdehyde level and some enzymatic activities in subclinical mastitis milk," African Journal of Biotechnology, vol. 10, no. 28, pp. 5534-5538, 2011.

[33] A. Lago, S. M. Godden, R. Bey, P. L. Ruegg, and K. Leslie, “The selective treatment of clinical mastitis based on on-farm culture results: I. Effects on antibiotic use, milk withholding time, and short-term clinical and bacteriological outcomes," Journal of Dairy Science, vol. 94, no. 9, pp. 4441-4456, 2011.

[34] S. Taponen, K. Supré, V. Piessens, E. van Coillie, S. de Vliegher, and J. M. K. Koort, "Staphylococcus agnetis sp. nov., a coagulasevariable species from bovine subclinical and mild clinical mastitis," International Journal of Systematic and Evolutionary Microbiology, vol. 62, no. 1, pp. 61-65, 2012.

[35] L. Quigley, O. O'Sullivan, C. Stanton et al., "The complex microbiota of raw milk," FEMS Microbiology Reviews, vol. 37, no. 5, pp. 664-698, 2013.

[36] H. Ceotto, J. dos Santos Nascimento, M. A. V. de Paiva Brito, and M. do Carmo de Freire Bastos, "Bacteriocin production by Staphylococcus aureus involved in bovine mastitis in Brazil," Research in Microbiology, vol. 160, no. 8, pp. 592-599, 2009.

[37] J. Rushton, J. Pinto Ferreira, and K. D. Stärk, "Antimicrobial resistance: the use of antimicrobials," OECD Food, Agriculture and Fisheries Papers, vol. 68, 2014.

[38] J. Hogan and K. L. Smith, "Coliform mastitis," Veterinary Research, vol. 34, no. 5, pp. 507-519, 2003.

[39] M. A. Muñoz, F. L. Welcome, Y. H. Schukken, and R. N. Zadoks, "Molecular epidemiology of two Klebsiella pneumoniae mastitis outbreaks on a dairy farm in New York State," Journal of Clinical Microbiology, vol. 45, no. 12, pp. 3964-3971, 2007.

[40] B. B. Kaliwal, S. O. Sadashiv, M. M. Kurjogi, and R. D. Sanakal, "Prevalence and antimicrobial susceptibility of coagulasenegative Staphylococci isolated from bovine mastitis," Veterinary World, vol. 4, no. 4, pp. 158-161, 2011.
[41] L. E. Redding, F. Cubas-Delgado, M. D. Sammel et al., "The use of antibiotics on small dairy farms in rural Peru," Preventive Veterinary Medicine, vol. 113, no. 1, pp. 88-95, 2014.

[42] E. Gentilini, G. Denamiel, A. Betancor, M. Rebuelto, M. Rodriguez Fermepin, and R. A. De Torres, "Antimicrobial susceptibility of coagulase-negative staphylococci isolated from bovine mastitis in Argentina," Journal of Dairy Science, vol. 85, no. 8, pp. 1913-1917, 2002.

[43] S. Piepers, L. de Meulemeester, A. de Kruif, G. Opsomer, H. W. Barkema, and S. de Vliegher, "Prevalence and distribution of mastitis pathogens in subclinically infected dairy cows in Flanders, Belgium," Journal of Dairy Research, vol. 74, no. 4, pp. 478-483, 2007.

[44] M. Brinda, V. Herman, and I. Fodor, "Phenotypic characterization of coagulase-negative staphylococci isolated from mastitic milk in cows," Lucrari Stiintifice Medicine Veterinara, vol. 43, pp. 97-101, 2010.

[45] B.-M. Thorberg, M.-L. Danielsson-Tham, U. Emanuelson, and K. Persson Waller, "Bovine subclinical mastitis caused by different types of coagulase-negative Staphylococci," Journal of Dairy Science, vol. 92, no. 10, pp. 4962-4970, 2009.

[46] G. Hedin and M. Widerström, "Endocarditis due to Staphylococcus sciuri," European Journal of Clinical Microbiology and Infectious Diseases, vol. 17, no. 9, pp. 673-675, 1998.

[47] F. Wallet, L. Stuit, E. Boulanger, M. Roussel-Del Vallez, P. Dequiedt, and R. J. Courcol, "Peritonitis due to Staphylococcus sciuri in a patient on continuous ambulatory peritoneal dialysis," Scandinavian Journal of Infectious Diseases, vol. 32, no. 6, pp. 697-698, 2000.

[48] T. Horri, Y. Suzuki, T. Kimura, T. Kanno, and M. Maekawa, "Intravenous catheter-related septic shock caused by Staphylococcus sciuri and Escherichia vulneris," Scandinavian Journal of Infectious Diseases, vol. 33, no. 12, pp. 930-932, 2001.

[49] S. Stepanović, P. Ježek, D. Vuković, I. Dakić, and P. Petráš, "Isolation of members of the Staphylococcus sciuri group from urine and their relationship to urinary tract Infections," Journal of Clinical Microbiology, vol. 41, no. 11, pp. 5262-5264, 2003.

[50] F. Cladera-Olivera, G. R. Caron, and A. Brandelli, "Bacteriocinlike substance production by Bacillus licheniformis strain P40," Letters in Applied Microbiology, vol. 38, no. 4, pp. 251-256, 2004.

[51] N. Y. Yount and M. R. Yeaman, "Immunocontinuum: perspectives in antimicrobial peptide mechanisms of action and resistance," Protein and Peptide Letters, vol. 12, no. 1, pp. 49-67, 2005.

[52] A. Pitkälä, M. Haveri, S. Pyörälä, V. Myllys, and T. HonkanenBuzalski, "Bovine mastitis in Finland 2001-prevalence, distribution of bacteria, and antimicrobial resistance," Journal of Dairy Science, vol. 87, no. 8, pp. 2433-2441, 2004.

[53] K. Östensson, V. Lam, N. Sjögren, and E. Wredle, "Prevalence of subclinical mastitis and isolated udder pathogens in dairy cows in Southern Vietnam," Tropical Animal Health and Production, vol. 45, no. 4, pp. 979-986, 2013. 

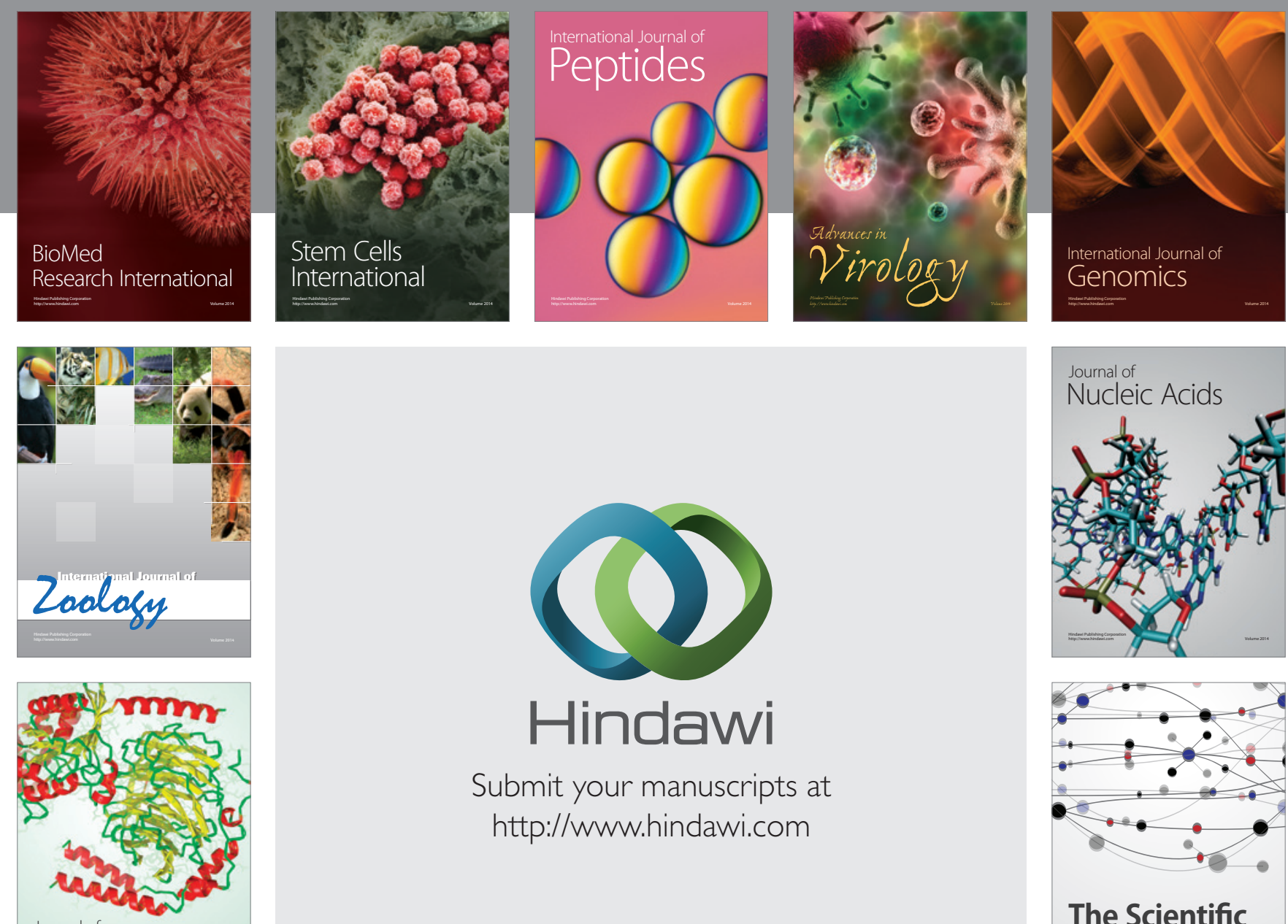

Submit your manuscripts at

http://www.hindawi.com

Journal of
Signal Transduction
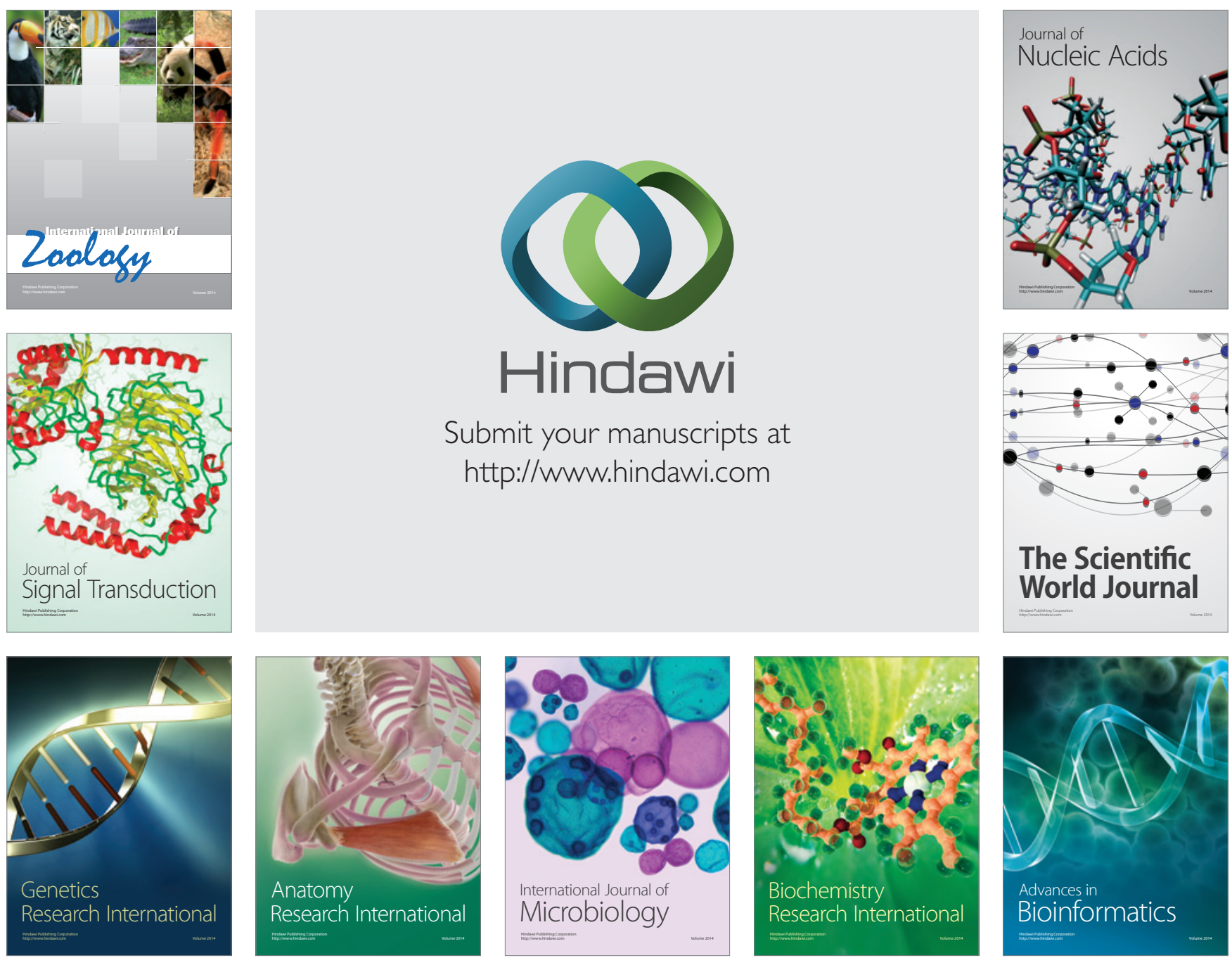

The Scientific World Journal
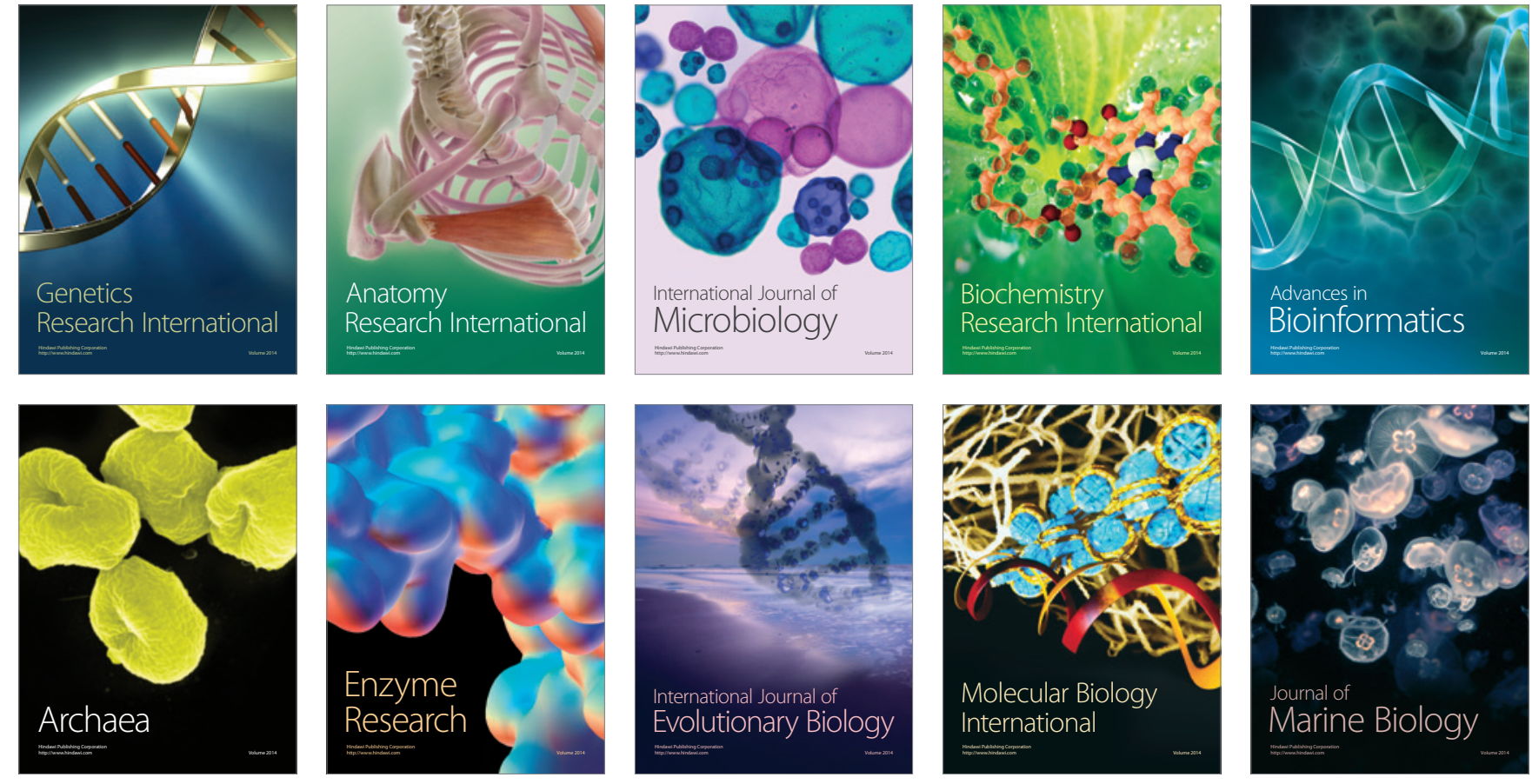